\title{
Pengaruh Determinan Struktur Modal dan Dampaknya Terhadap Nilai Perusahaan ( Studi Empiris Pada Perusahaan Property dan Real Estate yang Terdaftar di IDX 2014-2018)
}

(The Effect of The Capital Structure Deeterminant and The Impact on Firm Value : Empirical Study on Property and Real Estate COmpanies Listed on IDX 2014-2018))

\section{Nindi Vaulia Puspita', Muhammad Dian Ruhamak ${ }^{2}$}

${ }^{1}$ Program Studi Manajemen Universitas Kadiri, nindi.vaulia@unik-kediri.ac.id 1nindi.vaulia@unik-kediri.ac.id, 2dianru@unik-kediri.ac.id

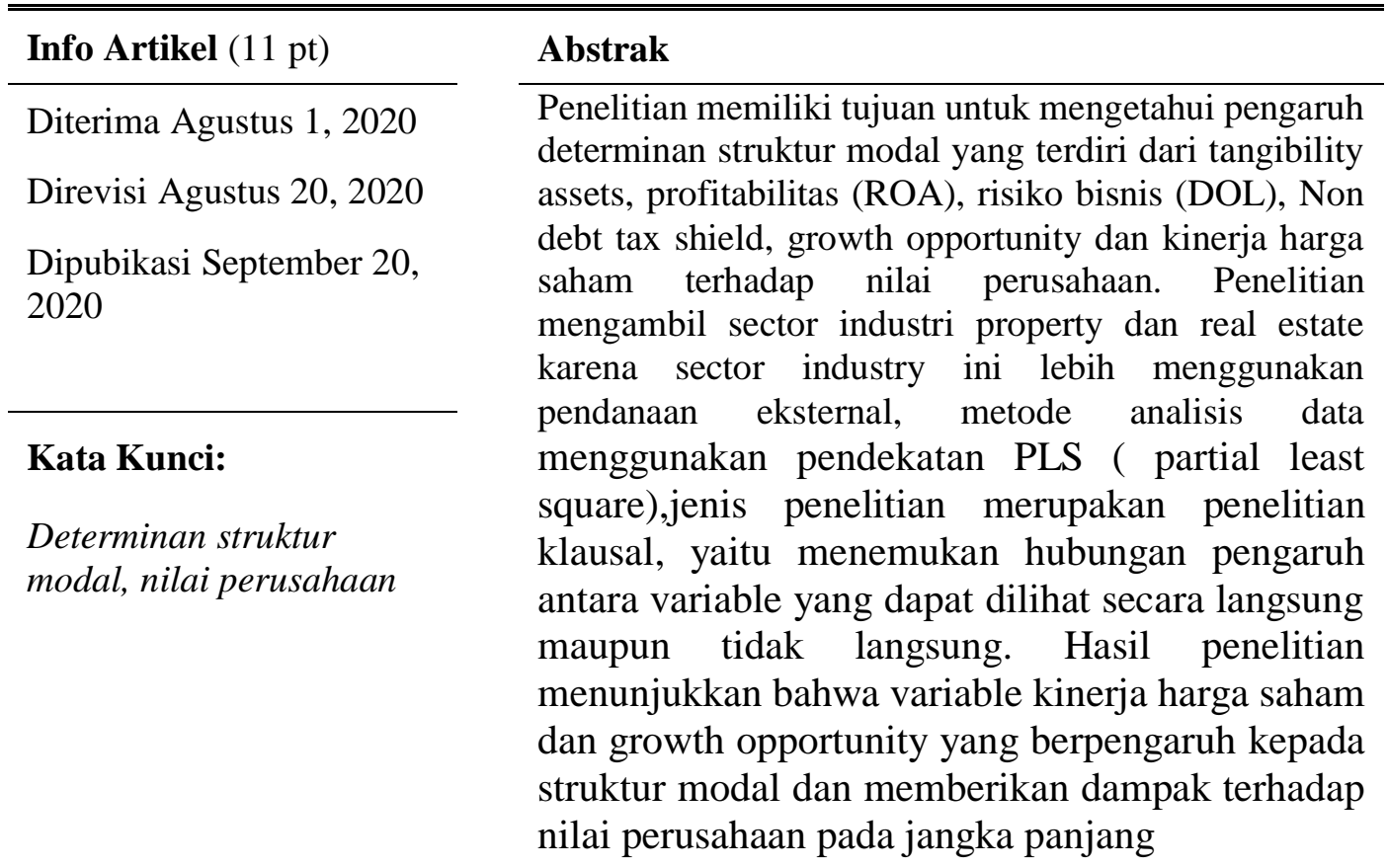

Keywords :

Determinat capital structure, firm value

\begin{tabular}{l} 
Abstract \\
\hline This study aims to determine the effect of the \\
determinants of capital structure consisting of asset \\
tangibility, profitability (ROA), business risk (DOL), \\
non debt tax shield, growth opportunity and stock price \\
performance on firm value. The study took the property \\
and real estate industrial sector because this industrial \\
sector uses external funding, the data analysis method \\
uses the PLS (partial least square) approach, this type \\
of research is a clausal study, which finds the influence \\
relationship between variables that can be seen directly \\
or indirectly. The results showed that stock price \\
\hline
\end{tabular}


performance and growth opportunity variables have an

effect on the capital structure and have an impact on

firm value in the long run

\section{PENDAHULUAN}

Perkembangan bisnis di sektor property dan real estate memiliki persaingan yang kompetitif dan terus bergerak dinamis, bahkan data menunjukkan bahwa walau sempat mengalami penurunan karena munculnya isu resesi yang dialami oleh indonesia, namun pada pasar saham penguatan IHSG dipimpin oleh binis sector property dan real estate pada triwulan ketiga (beritatagar.id,2019).

Sector bisnis property dan real estate merupakan industry yang menggunakan dana hutang dibandingkan dengan modal sendiri, namun dalam melakukan kegiatan operasional sektor industry property dan real estate menggunakan aktiva tetap yang memberikan efek kepada kas dalam jangka pendek (Dewi \& Sudiartha, 2017).

Modal merupakan komponen vital dalam perusahaan, karena menjadi factor dominan dalam kegiatan operasionalnya, oleh karena itu pengelolaan modal memerlukan manajemen yang professional sehingga dapat tercapainya suatu tujuan perusahaan dalam jangka panjang atau jangka pendek(Salvatore, 2014). (Houston, 2015) menyatakan bahwa setiap perusahaan membutuhkan dana untuk melakukan pengembangan bisnisnya, baik dana menggunakan sumber internal maupun ekternal. Keputusan pendanaan berperan secara krusial terhadap kesejahteraan pemilik dan kelangsungan hidup perusahaan. Munculnya beberapa teori dalam menjelaskan perbedaan keputusan pendanaan pada setiap bagian sesuai dengan keseimbangan antara beban dan manfaat, keseimbangan informasi dan insentif pengendalian perusahaan (Panda \& Nanda, 2020).

Tujuan jangka panjang perusahaan adalah memaksimalkan kemakmuran pemegang sahamnya dengan cara meningkatkan nilai perusahaan (Brigham, 2015). Peningkatan nilai perusahaan dapat diraih oleh perusahaan saat pengambilan keputusan pendanaan dapat dijalankan secara maksimal oleh manajer perusahaan, salah satu keputusan terkait pendanaan adalah kebijakan struktur modal yang digunakan oleh perusahaan. Posisi keuangan perusahaan merupakan efek secara langsung dari efektivitas struktur modal, sehingga stuktur modal adalah komponen penting yang harus lebih diperhatikan oleh perusahaan(Alipour et al., 2015). 
Proporsi struktur modal yang optimal akan menghasilkan return bagi perusahaan secara maksimal. Struktur modal dan nilai perusahaan yang optimal dapat tercapai saat kombinasi antara ekuitas dan pembiayaan utang yang maksimal namun mampu meminimalkan WACC ( weight average cost of capital) (Wardani et al., 2020)

(Brigham, 2015) menyatakan bahwa struktur modal yang dapat memaksimalkan antara risiko dwngan pengembalian, sehingga nilai harga saham menjadi maksimal dan memiliki rasio utang yang lebih rendah.

Modigliani dan miller (1963) dalam teori struktur modal menyatakan bahwa pajak yang dibayar oleh perusahaan yang pendanaannya berasal dari utang menjadi lebih kecil (tax deductible) karena bunga utang mengurangi keuntungan kena pajak (EAT).

Struktur aktiva (tangibilitas) perusahaan semakin besar kepemilikan perusahaan atas aktiva berwujud maka pembiayaan perusahaan dalam memakai utang akan meningkat. Teori trade-off (myers,1984) menjelaskan bahwa jaminan dalam pendanaan hutang adalah kepemilikan perusahaan asset berwujud yang lebih besar. (Brigham, 2015) menyatakan bahwa keputusan struktur modal perusahaan dipengaruhi oleh jumlah peningkatan asset tangibility perusahaan yang merupakan hasil dari penggunaan utang sehingga asset perusahaan mampu dijadikan jaminan pinjaman.(Jubaedah \& Fadila, 2018), (Sofat \& Singh, 2017), dan (Bolarinwa \& Adegboye, 2020) menyatakan bahwa tangibility memberikan pengaruh yang positif terhadap struktur modal, (Saif-Alyousfi et al., 2020) menyatakan bahwa tangibility memberikan pengaruh terhadap struktur modal. sedangkan penelitian (Dewi \& Sudiartha, 2017) menyatakan bahwa tangibility tidak memberikan pengaruh terhadap struktur modal, hasil tersebut sama dengan hasil penelitian (Alipour et al., 2015) yang menyatakan bahwa tangibilitas dengan struktur modal perusahaan tidak memiliki pengaruh.

Profitabilitas adalah tolok ukur kinerja perusahaan dalam mewujudkan return positif pada waktu tertentu (Brigham, 2015). Kemampuan yang baik dalam mendanai investasi dari laba ditahan adalah perusahaan yang memiliki tingkat profitabilitas yang tinggi (A.A Zaid et al., 2020). Menurut (Ahmed Sheikh et al., 2018) melihat adanya 
pengaruh profitabilitas melalui ROA (return on assets) terhadap struktur modal. (Arsov \& Naumoski, 2016) yang menguji perusahaan di eropa timur juga menemukan bahwa perusahaan yang mempunyai nilai utang rendah dalam struktur modalnya maka tingkat profitabilitasnya tinggi. Kondisi sebaliknya ditujukkan dalam penelitian (Bolarinwa \& Adegboye, 2020) menemukan bahwa profitabilitas tidak memberikan pengaruh yang signifikan terhadap struktur modal. Begitu juga penelitian (Vo \& Ellis, 2017) yang menggunakan perusahaan di Vietnam menunjukkan bahwa memiliki nilai hutang yang lebih tinggi saat perusahaan juga menghasilkan profitabilitas yang tinggi dan memiliki cadangan dana internal yang lebih besar.

Risiko bisnis adalah kondisi tidak pasti yang dihadapi oleh perusahaan dalam melaksanakan kegiatan bisnisnya (Brigham, 2015). Risiko bisnis dapat meningkat ketika perusahaan menggunakan pendanaan dari utang, risiko ini muncul karena adanya beban biaya utang perusahaan, semakin besar beban biaya maka semakin besar risiko yang dihadapi. Kondisi ini sesuai dengan penelitian terdahulu (Mangesti Rahayu et al., 2019) menyatakan bahwa risiko bisnis berpengaruh positif namun tidak signifikan terhadap struktur modal, sedangkan penelitian (Kyissima et al., 2019) menyatakan bahwa risiko bisnis berpengaruh signifikan terhadap struktur modal. Kondisi sebaliknya terlihat dari penelitian (Sofat $\&$ Singh, 2017) yang menyatakan bahwa risiko bisnis tidak bepengaruh terhadap struktur modal.

Non debt tax shield merupakan penghematan pajak yang muncul karena adanya beban depresiasi aktiva berwujud yang memberikan pengaruh kepada struktur modal perusahaan (Brigham, 2015). Non-debt tax shields diukur dengan menggunakan rasio nilai depresiasi dan amortisasi terhadap total asset yang dimiliki oleh perusahaan (Brigham, 2015). Myers (1984) menyatakan bahwa dengan memakai sumber dana hutang akan mendapat manfaat pajak berupa pengurangan pajak (tax deduction) yang dibayarkan. Penelitian yang dilakukan oleh(Panda \& Nanda, 2020), (Sofat \& Singh, 2017) dan (Al-Najjar \& Hussainey, 2011) menyatakan bahwa non-debt tax shield berpengaruh positif dan signifikan terhadap struktur modal, dimana perusahaan yang memiliki non-debt tax shield lebih tinggi akan memilih untuk mengurangi pendanaan hutang, penelitian sebaliknya didapatkan oleh (Alipour et al., 2015) menyatakan bahwa 
non-debt tax shield yang tidak signifikan terhadap struktur modal.

Growth opportunity adalah peluang pertumbuhan perusahaan dalam mengembangkan usahanya dimasa yang akan datang. (Houston, 2015) Tingkat growth opportunity yang tinggi menunjukkan bahwa perusahaan mampu untuk menghasilkan keuntungan di masa yang akan datang. Hasil penelitian (Vo \& Ellis, 2017) dan (Obradovich, John and Gill, 2017) menunjukkan bahwa growth opportunity berpengaruh positif dan signifikan terhadap struktur modal, sedangkan hasil penelitian (Kodongo et al., 2014) dan (Stelk et al., 2018)menyatakan bahwa growth opportunity tidak berpengaruh signifikan terhadap struktur modal.

Kinerja saham merupakan salah satu factor yang menjadi pertimbangan perusahaan dalam pengambilan kebijakan struktur modal. (Kang \& Gray, 2014) dalam penelitiannya menemukan kinerja harga saham di kawasan Asia Pasifik memiliki pengaruh terhadap keputusan struktur modal perusahaan. Semakin baik kinerja saham dapat menarik kepercayaan investor dalam memperoleh earning yang tinggi di masa mendatang. Penelitian ini sejalan dengan penelitian (Arsov \& Naumoski, 2016). (SaifAlyousfi et al., 2020)menyatakan bahwa kinerja harga saham yang diukur menggunakan maket-to book ratio tidak memberi pengaruh terhadap struktur modal. (Dewi \& Sudiartha, 2017) mengungkapkan bahwa manajer pada perusahaan industri non-keuangan dan retail yang diteliti tidak mampu memainkan peran time the market sehingga penerbitan hutang yang dilakukan tidak mempertimbangkan harga ekuitas yang tinggi. Variable determinan kinerja harga saham digunakan karena sensitivitas pasar modal di Indonesia dengan kondisi market global.

Nilai perusahaan adalah nilai yang mencerminkan persepsi pemegang saham terhadap nilai ekuitas yang dimiliki perusahaan (Houston, 2015). Berbagai kebijakan akan diambil manajemen dalam upaya untuk meningkatkan nilai perusahaan melalui peningkatan kemakmuran pemilik dan pemegang saham yang tercermin dalam harga saham (Salvatore, 2014). Sehingga makin tinggi nilai saham akan mencerminkan tingginya nilai perusahaan (Rani et al., 2019). Hasil penemuan (Ahmed Sheikh et al., 2018) , bahwa pembiayaan dengan hutang baik jangka pendek maupun jangka panjang 
pada perusahaan di Pakistan dan Vietnam juga dapat menurunkan nilai perusahaan. Namun, penelitian (Iqbal et al., 2016) menemukan pengaruh yang sebaliknya, bahwa perusahaan yang menggunakan pendanaan hutang yang meningkat dapat meningkatkan nilai perusahaan perhotelan di India. Sementara itu (Bonazzi \& Iotti, 2014) dan (Kang \& Gray, 2014) tidak menemukan adanya pengaruh antara struktur modal dengan nilai perusahaan.

Penelitian dilakukan dengan tujuan untuk mengetahui bagaimana pengaruh determinan struktur modal dan dampaknya terhadap nilai perusahaan pada perusahaan property dan real estate yang terdaftar di IDX dalam rentang waktu 2014-2018 dengan rincian: (a) mengetahui pengaruh tangibility assets yang terhadap struktur modal perusahaan property dan real estate; (b) mengetahui pengaruh profitability yang dicerminkan dengan return on assets (ROA) terhadap struktur modal Perusahaan Property Dan Real Estate; (c) mengetahui pengaruh non-debt tax shield terhadap struktur modal Perusahaan Property Dan Real Estate; (d) Mengetahui pengaruh risiko bisnis yang dicerminkan dengan DOL terhadap struktur modal Perusahaan Property Dan Real Estate; (e) mengetahui pengaruh growth opportunity terhadap struktur modal Perusahaan Property Dan Real Estate; (f) mengetahui pengaruh kinerja harga saham yang dicerminkan melalui market book ratio terhadap struktur modal Perusahaan Property Dan Real Estate; (g) mengetahui pengaruh struktur modal terhadap nilai perusahaan yang dicerminkan dengan Tobin Q pada Perusahaan Property Dan Real Estate.

Urgensi penelitian adalah untuk mengetahui factor-faktor determinan struktur modal yang dominan terhadap nilai perusahaan, karena penempatan proporsi struktur modal yang tepat dapat mencapai tujuan jangka Panjang perusahaan yaitu meningkatnya nilai perusahaan property dan real estate yang pada akhirnya akan memberikan kemakmuran kepada investor.

\section{METODE PENELITIAN}

\section{Populasi \& Sampel}

Populasi penelitian menggunakan perusahaan sebanyak 62 perusahaan property dan real estate yang telah terdaftar pada IDX ( Indonesian stock Exchange). Teknik 
pengambilan sampel menggunakan purposive sampling, yaitu menentukan kriteriakriteria tertentu untuk pengambilan data yang terdiri dari: (1) perusahaan bergerak dalam bidang property dan real estate yang terdaftar di IDX; (2) perusahaan memiliki laporan keuangan yang lengkap semenjak tahun 2014-2018. Sedangkan sampel penelitian terdiri dari 36 perusahaan property dan real estate.

\section{Desain Penelitian}

Desain penelitian adalah desain klausal, dimana mnecari hubungan pengaruh antara variable yang dapat dilihat secara langsung maupun tidak langsung yang terdiri dari tangible assets, profitabilitas, Non debt tax shield (NDTS), risiko bisnis, growth opportunity, dan kinerja harga saham terhadap variable struktur modal dan nilai perusahaan.

\section{Definisi Operasional Dan Pengukuran Variabel}

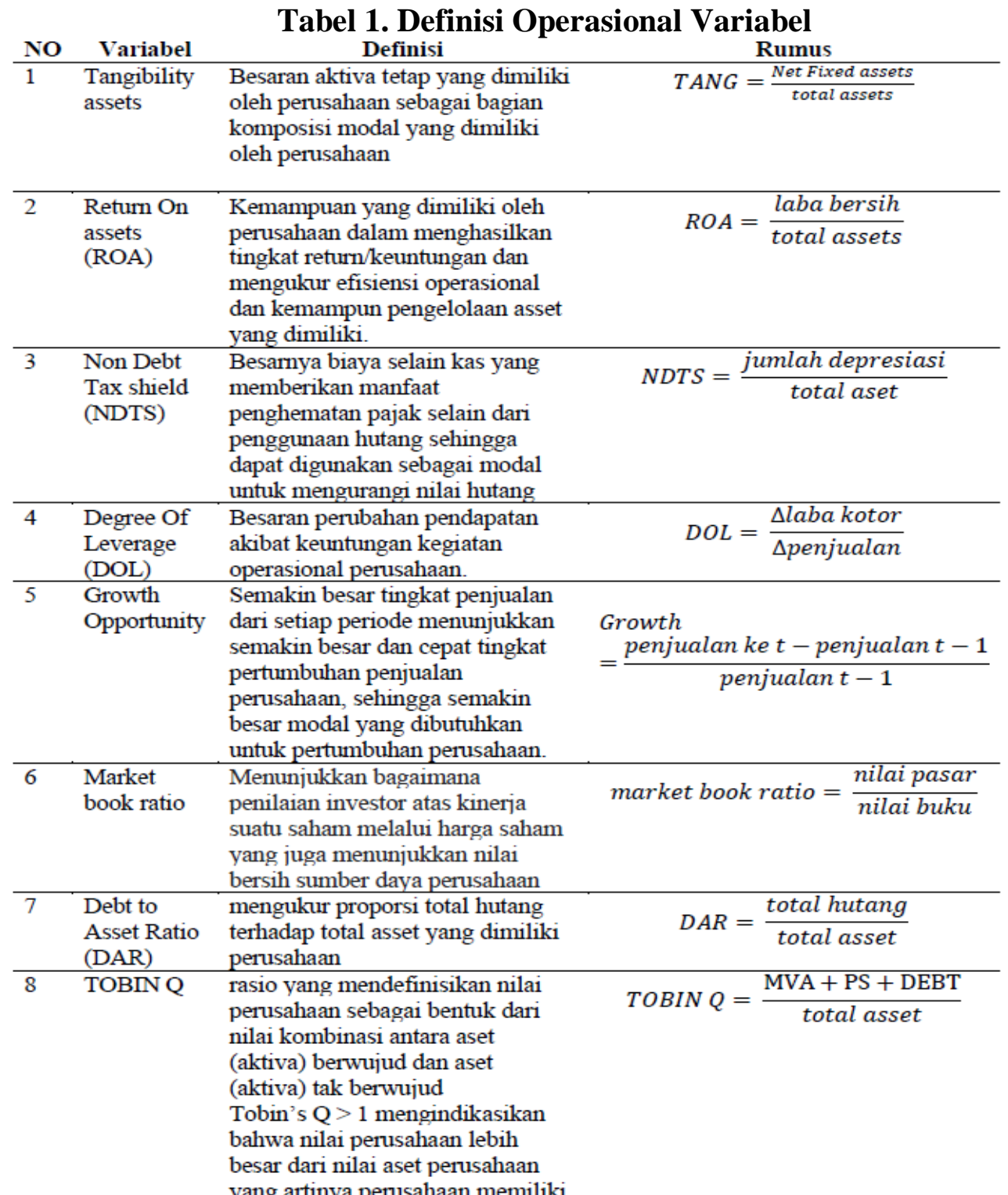


Sumber : (Brigham, 2015)

\section{Kerangka Konseptual Penelitian}

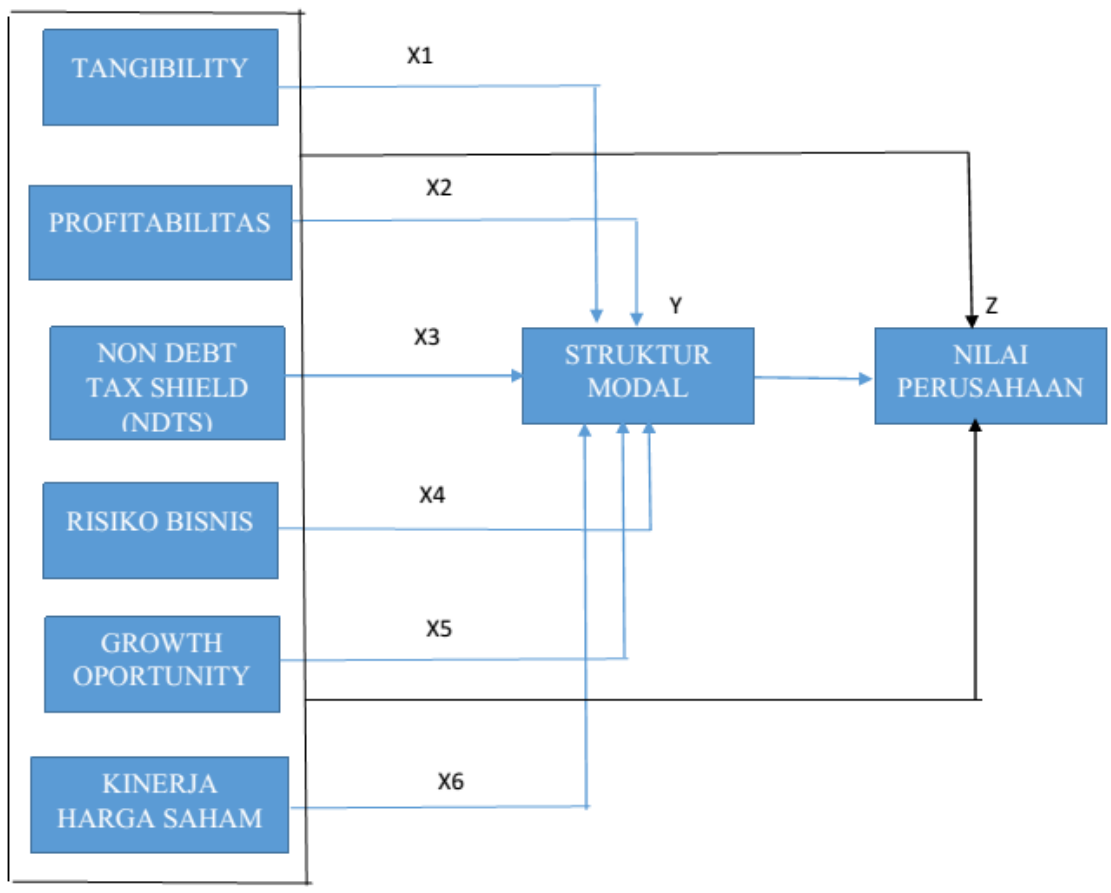

\section{Teknik Analisis Data}

Pada penelitian ini analisa data menggunakan pendekatan PLS (partial least square), dimana PLS merupakan model dari persamaan structural Equation Modeling (SEM) yang berbasis komponen atau varian. Penelitian ini akan menggunakan pendekatan R-Square (R2), Q-Square Predictive Relevance (Q2), dan Goodness of Fit (GoF).

\section{HASIL DAN PEMBAHASAN \\ Evaluasi Outler Model}


Convergent Validity dari measurement model menggunakan indikator reflektif dapat ditunjukkan dari korelasi antar skor indikator dengan skor konstruknya, Indikator individu dikatakan valid apabila mempunyai nilai outler loading diatas $(>0,60)$ (Ghozali, 2011). Berdasarkan hasil uji yang dilakukan menunjukkan masing-masing konstruk memiliki nilai konstruk lebih dari yang dipersyaratkan dengan nilai signifikansi berada pada level 0,05 menunjukkan bahwa variable memenuhi syarat valid sesuai kriteria discriminant validity. Composite Reliability dan Cronbach Alpha. Suatu pengukuran dapat disebut reliabel, jika composite reliability dan cronbach alpha bernilai lebih besar dari 0,70 (Ghozali, 2011). Berdasarkan hasil hitung data diperoleh bahwa data lebih dari 0,70 sehingga memenuhi persyaratan sebagai data oreliable.

\section{Pengaruh Tangibility assets terhadap Struktur modal}

Pengujian hipotesis diperoleh bahwa tangibility assets memiliki pengaruh negatif signifikan terhadap struktur modal pada Industri property dan real estate yang terdaftar pada IDX dalam rentang waktu 2014-2018. Hal ini ditunjukkan oleh nilai koefisien sebesar -0,323 yang menunjukkan bahwa berarti $\mathrm{H} 1$ tidak diterima, kondisi ini menunjukkan bahwa tangibility assets tidak berpengaruh terhadap struktur modal. Penelitian ini sesuai penelitian yang dilaksanakan oleh (Dewi \& Sudiartha, 2017) dan (Alipour et al., 2015).

\section{Pengaruh Profitabilitas terhadap struktur modal}

Hasil pengujian profitabilitas terhadap struktur modal menunjukkan koofisien sebesar 0,14 dengan nilai t-statistic 3,65 lebih besar dari nilai kritis, hal ini menunjukkan bahwa H1 ditolak yang memberikan arti bahwa profitabilitas yang dicerminkan dengan ROA tidak berpengaruh terhadap struktur modal. Hasil penelitian ini sesuai dengan penelitian (Bolarinwa \& Adegboye, 2020) dan (Vo \& Ellis, 2017)

\section{Pengaruh Non Debt Tax Shield terhadap Struktur Modal}

Nilai non debt tax shield (NDTS) tidak berpengaruh secara signifikan terhadap struktur modal perusahaan, hasil penelitian ini sesuai dengan penelitian yang dilaksanakan oleh (Alipour et al., 2015). Kondisi ini terjadi karena penghematan pembayaran atas pajak selain karena faktor hutang menyebabkan laba meningkat, sehingga perusahaan lebih memilih struktur modal dengan penggunaan dana internal, sehingga variable NDTS tidak memberikan pengaruh terhadap struktur modal perusahaan. 


\section{Pengaruh Degree of leverage Terhadap struktur modal}

Pengujian untung degree of leverage menunjukkan bahwa DOL tidak memberikan pengaruh terhadap struktur modal perusahaan, kondisi ini muncul karena investor lebih melihat kepada kinerja perusahaan dalam meningkatkan laba dibanding kepada peningkatan volume penjualan, hasil penelitian ini sesuai dengan penelitian yang dilakukan oleh (Mangesti Rahayu et al., 2019) dan (Sofat \& Singh, 2017)

\section{Pengaruh Growth opportunity terhadap struktur modal}

Hasil dari growth opportunity dengan struktur modal menunjukkan bahwa growth opportunity memberikan pengaruh walaupun tidak signifikan, kondisi ini menunjukkan bahwa growth opportunity perusahaan yang semakin meningkat akan lebih memilih penggunaan dana internal perusahaan, penelitian ini searah dengan pecking order theory dan juga penelitian yang telah dilakukan oleh (Kodongo et al., 2014) dan (Stelk et al., 2018).

\section{Pengaruh Kinerja harga saham terhadap struktur modal}

Kinerja harga saham yang di proyeksikan dengan market book ratio dicerminkan melalui harga saham, dari hasil pengujian yang dilakukan pada perusahaan property dan real estate menunjukkan bahwa MBR dipengaruhi oleh struktur modal perusahaan, kondisi ini menunjukkan dukungan teori Modigliani dan Miller bahwa dengan peningkatan modal ekternal akan meningkatkan nilai MBR, hasil penelitian ini searah dengan penelitian yang telah dilaksanakan (Kang \& Gray, 2014).

\section{Pengaruh struktur modal terhadap nilai perusahaan}

Dari hasil penelitian menunjukkan bahwa peningkatan struktur modal akan memberikan efek kepada penurunan nilai perusahaan, hasil ini searah dengan penelitian yang telah dilaksanakan oleh (Ahmed Sheikh et al., 2018) dan (Ekadjaja, 2017). Kondisi ini terjadi karena semakin besar perusahaan dibiayai dari dana eksternal makan akan semakin turun nilai perusahaan, seperti trade off theory saat perusahaan lebih memilih penggunaan dana eksternal maka semakin besar Net present value yang didapatkan, namun semakin tinggi risiko kebankrutan yang ditanggung perusahaan 


\section{V.KESIMPULAN DAN SARAN}

\section{Kesimpulan}

Kesimpulan dari hasil penelitian yang telah dilaksanakan adalah Tangibility assets, profitabilitas, DOL, NDTS tidak memberikan pengaruh walaupun kecil terhadap struktur modal, namun variable growth opportunity walaupun kecil memberikan pengaruh kepada struktur modal, sedangkan kinerja harga saham berpengaruh signifikan terhadap struktur modal, begitu pula dengan struktur modal terhadap nilai perusahaan memberikan pengaruh yang cukup besar, dimana saat penggunaan struktur modal eksternal dengan kompisis yang lebih besar akan menurunkan nilai perusahaan di bidang property dan real estate yang list di IDX dalam jangka waktu 2014-2018

\section{Saran}

Penelitian selanjutnya lebih dikembangkan dengan menggunakan sector industry lain dengan memasukkan variable makro ekonomi dalam penentuan struktur modal. Selain itu disarankan kepada perusahaan di bidang industry property dan real estate lebih mendapatkan perhatian manajemen karena kecenderungan perusahaan property dan real estate yang lebih banyak menggunakan sumber dana eksternal dibandingkan internal, sehingga nilai perusahaan juga menurun di mata investor

\section{UCAPAN TERIMA KASIH}

Terima kasih atas keyakinan yang diberikan untuk melakukan penelitian bersumber dari pendanaan Hibah Simlitabmas dengan skema Penelitian Dosen Pemula (PDP). Terima kasih kepada civitas Universitas Kadiri atas segala dukungan, baik berupa moril maupun fasilitas penunjang dalam menyelesaikan penelitin ini.

\section{DAFTAR PUSTAKA}

A. A Zaid, M., Wang, M., T.F. Abuhijleh, S., Issa, A., W. A. Saleh, M., \& Ali, F. (2020). Corporate governance practices and capital structure decisions: the moderating effect of gender diversity. Corporate Governance (Bingley), 20(5), 939-964. https://doi.org/10.1108/CG-11-2019-0343

Ahmed Sheikh, N., Wang, Z., Bao, H. X. H., Gong, C. M., Rao, P., Kumar, S., 
Madhavan, V., Brigham \& Houston., Reinhard, L., Li, S., Nasir, M. A., Morgan, J., Huang, X., Kabir, R., Zhang, L., Hang, M., Geyer-Klingeberg, J., Rathgeber, A. W., Stöckl, S., Haron, R. (2018). Article information : A dynamic approach.

Quarterly Review of Economics and Finance, 31(1), 245-259.

https://doi.org/10.1016/j.qref.2018.07.001

Al-Najjar, B., \& Hussainey, K.(2011). Revisiting the capital-structure puzzle: UK evidence. Journal of Risk Finance, 12(4), 329-338.

https://doi.org/10.1108/15265941111158505

Alipour, M., Mohammadi, M. F. S., \& Derakhshan, H.(2015). Determinants of capital structure: An empirical study of firms in Iran. International Journal of Law and Management, 57(1), 53-83. https://doi.org/10.1108/IJLMA-01-2013-0004

Arsov, S., \& Naumoski, A.(2016). Determinante strukture kapitala: Empirijska studija kompanija iz odabranih post-tranzicijskih ekonomija. Zbornik Radova Ekonomskog Fakultet Au Rijeci, 34(1), 119-146. https://doi.org/10.18045/zbefri.2016.1.119

Bolarinwa, S. T., \& Adegboye, A. A.(2020). Re-examining the determinants of capital structure in Nigeria. Journal of Economic and Administrative Sciences, ahead-of$p$ (ahead-of-print). https://doi.org/10.1108/jeas-06-2019-0057

Bonazzi, G., \& Iotti, M.(2014). Interest coverage ratios (ICRs) and financial sustainability : Application to firms with bovine dairy livestock. American Journal of Agricultural and Biological Science, 9(4), 482-489.

https://doi.org/10.3844/ajabssp.2014.482.489

Brigham.(2015). Dasar Dasar Manajemen Keuangan(14th ed.). salemba empat.

Dewi, D., \& Sudiartha, G.(2017). Pengaruh Profitabilitas, Ukuran Perusahaan, Dan Pertumbuhan Aset Terhadap Struktur Modal Dan Nilai Perusahaan. E-Jurnal Manajemen Universitas Udayana, 6(4), 242635.

Ekadjaja, L.(2017). Linawaty dan Ekadjaja: Analisis Pengaruh Leverage Terhadap Nilai Perusahaan... XXII(01), 164-176.

Ghozali, I. (2011). Struktural Equation Modeling(4th ed.). Badan Penerbit UNDIP. Houston, B. (2015). Dasar dasar Manajemen keuangan(11th ed.). salemba empat.

Iqbal, A., Raza, H., Aslam, M. F., \& Mubin, M.(2016). Impact of Leverages on Share Price : Evidence from Cement Sector of Pakistan. Industrial Engineering Letters, 6(6), 44-48-48.

Jubaedah, \& Fadila, A.(2018). Determinan Struktur Modal (Studi Pada Perusahaan Manufaktur). Jurnal Mebis (Manajemen Dan Bisnis), 3(2), 1-13. https://doi.org/10.33005/mebis.v3i2.32

Kang, H., \& Gray, S. J.(2014). Emerging Market Firms in the Global Economy. International Finance Review, 15, 233-254. https://doi.org/10.1108/S15693767201415

Kodongo, O., Mokoteli, T., \& Maina, L. (2014). Capital structure, profitability and firm value: panel evidence of listed firms in Kenya Odongo. Munich Personal RePec Archive, 6(57116).

Kyissima, K. H., Xue, G. Z., Yapatake Kossele, T. P., \& Abeid, A. R.(2019). Analysis of capital structure stability of listed firms in China. China Finance Review International, 10(2), 213-228. https://doi.org/10.1108/CFRI-05-2018-0044

Mangesti Rahayu, S., Suhadak, \& Saifi, M.(2019). The reciprocal relationship between 
profitability and capital structure and its impacts on the corporate values of manufacturing companies in Indonesia. International Journal of Productivity and Performance Management, 69(2), 236-251. https://doi.org/10.1108/IJPPM-052018-0196

Obradovich, John and Gill, A.(2017). The Impact of Corporate Governance and Financial Leverage on the Value of American Firms. Jordan Journal of Business Administration, 12(4), 899-917. https://doi.org/10.12816/0034973

Panda, A. K., \& Nanda, S.(2020). Determinants of capital structure : a sector-level analysis for Indian manufacturing firms. International Journal of Productivity and Performance Management, 69(5), 1033-1060. https://doi.org/10.1108/IJPPM-122018-0451

Rani, N., Yadav, S. S., \& Tripathy, N.(2019). Capital structure dynamics of Indian corporates. Journal of Advances in Management Research, 17(2), 212-225. https://doi.org/10.1108/JAMR-12-2017-0125

Saif-Alyousfi, A. Y. H., Md-Rus, R., Taufil-Mohd, K. N., Mohd Taib, H., \& Shahar, H. K.(2020). Determinants of capital structure : evidence from Malaysian firms. AsiaPacific Journal of Business Administration, ahead-of-p(ahead-of-print). https://doi.org/10.1108/apjba-09-2019-0202

Salvatore, D.(2014). EKONOMI INTERNASIONAL (9th ed.). Salemba Empat.

Sofat, R., \& Singh, S.(2017). Determinants of capital structure : an empirical study of manufacturing firms in India. International Journal of Law and Management, 59(6), 1029-1045. https://doi.org/10.1108/ijlma-05-2016-0051

Stelk, S., Park, S., H., Medcalfe, S., \& Dugan, M. T.(2018). An additional analysis of estimation techniques for the degree of financial leverage. Review of Financial Economics, 36(3), 220-231. https://doi.org/10.1016/j.rfe.2017.03.005

Vo, X. V., \& Ellis, C.(2017). An empirical investigation of capital structure and firm value in Vietnam. Finance Research Letters, 22, 90-94. https://doi.org/10.1016/j.frl.2016.10.014

Wardani, D. K., Mardani, R. M., \& Priyono, A. A.(2020). Determinan Struktur Modal Terhadap Nilai Perusahaan (Studi Kasus Pada Perusahaan Manufaktur yang terdaftar di Bursa Efek Indonesia Sub Sektor Makanan dan Minuman). Jurnal Ilmiah. Riset. Manajemen, 9(08), 164-181. 